\title{
TEACHING SPEAKING THROUGH SHORT DIALOGUE AT THE ELEVENTH GRADE STUDENTS OF SMAN 1 PELAIHARI
}

\section{Erni Nadia ${ }^{1}$ \\ 1. English Education Study Program Faculty of Teacher Training and Education Nahdlatul Ulama University Of South Kalimantan}

\begin{abstract}
Speaking is the process of building and sharing meaning through the use of verbal and non-verbal symbols. Speaking is a crucial part of second language teaching and learning. The objective of this research is to describe how the process of teaching speaking through short dialogue at the Eleventh grade students of SMAN 1 Pelaihari school year 2019/2020. This research paper is aimed at describing the process of teaching speaking through short dialogue focused on the curriculum, method and technique of teaching speaking, teaching media, and system of evaluation. The source of data is teaching learning process of dialogue technique at SMAN 1 Pelaihari and documents. In this research, the writer does the classroom observation, interview and document to the English teacher. Based on the data analysis, the writer finds that the result of teaching speaking by using short dialogue at the eleventh grade students of SMAN 1 Pelaihari as follows: 1). The curriculum of SMAN 1 Pelaihari, especially at the eleventh level, uses Kurikulum 2013. In Kurikulum 2013, the goal of teaching speaking is to gain the students to be able to communicate in English on the elementary level. Consequently, they can express various feelings or senses; 2). Method and technique of teaching speaking. In teaching speaking the English teacher uses Communicative approach and dialogue technique; 3). Media of teaching speaking. Media a very needed to successful teaching learning process, so the English teacher of SMAN 1 Pelaihari uses a whiteboard and cassette (CD); and 4). System evaluation of speaking activities. To evaluate the students' performance the teacher gives comments and mark, this way is very needed for a teacher to know the student's capability and to make the lesson better. Therefore, the result of teaching speaking through dialogue is satisfying.
\end{abstract}

Key Words: Teaching Speaking, Short Dialogue

\section{INTRODUCTION}

Language is a means of communication. People use language as an instrument to form their thought, emotions, and activities. Language cannot be separated from human beings because it plays an important part in human beings activities. Learning a language is not for knowledge and comprehension only, but it is for communication as well. As we know it, English is one of the foreign languages in Indonesia, where, from time to time it gains important role in all aspects of life, particularly in the field of science and technology. Speaking is the process of building and sharing meaning 
through the use of verbal and non-verbal symbols. Speaking is a crucial part of second language learning and teaching. However, today's world requires that the goal of teaching speaking should improve students' communicative skills because students can express themselves and learn how to use a language.

For this reason, the English teacher of SMAN 1 Pelaihari should apply the appropriate method and technique of teaching speaking. The method used by the teacher is the Communicative approach. In a communicative approach, language is primarily a tool of communication. Thus, learning a language means learning to perform communicative speech acts with it as suggested by Bickerton (1996:1). Therefore, to successful this method the teacher needs a technique and one of them is by using dialogue. The reason is transactional language (dialogue) will helps the students practice in speech, pronunciation, intonation and stress like the native speaker.

Based on the phenomenon above, the writer conducts research entitled "Teaching Speaking Through Short Dialogue at the Eleventh Grade Students of SMAN 1 Pelaihari”.

\section{RESEARCH METHODOLOGY}

In this research, the researcher tries to conduct descriptive qualitative research. So, the writer will describe the process of "Teaching Speaking Through Short Dialogue at the Eleventh Grade Students of SMAN 1 Pelaihari”.

\section{A. Method of Collecting Data}

Data have a very important role in research because without data it is impossible to get the result of the research. To obtain the data, the research has to use instruments of collecting data, namely:

\section{Observation}

Observation is monitoring with a systematic phenomenon which is investigated. In other words, the researcher observes the teaching learning process and drawing the conclusion of whatever happens in the teaching-learning process using short dialogue.

\section{Interview}

Fraenkel (1993:385) describes that an interview is an important way for a researcher to check the accuracy of the impressions of what he or she has gained through observation. The researcher purpose of interviewing an English teacher is to find out his mind, what he thinks or how he feels about something. 


\section{Document}

The document is a kind of source data involves anything notes aimed to examine research stated by Moleong (1995:161). In research, the researcher may use a syllabus, teaching material, lesson plan, and recording interview as the document.

\section{B. The Technique for Analyzing Data}

In this research, the researcher conducts descriptive qualitative research which describes the process of teaching speaking through dialogue at the eleventh grade

students of SMAN 1 Pelaihari. So, in this case, the researcher does not need statistic data. The follows are the procedures for analyzing the data:

1. Describing the teaching speaking components that covers:

a. The curriculum involves the goal, syllabus, and teaching material.

b. Method and technique of teaching speaking.

c. Media of teaching speaking.

d. System of evaluation used by the teacher

2. Discussing the findings of the research. Describes the process of teaching speaking through dialogue based on teaching speaking components.

3. Drawing conclusion briefly and then giving some suggestion.

\section{THE RESULT OF RESEARCH}

\section{A. The Result of Interview}

\section{Curriculum}

Today SMAN 1 Pelaihari, especially for the eleventh grade students, uses Kurikulum 2013. The English teacher states that: "Kurikulum 2013 now is applied at SMAN 1 Pelaihari. In Kurikulum 2013, the standard competency of teaching English at the eleventh grade students of SMAN 1 Pelaihari is to train the students to be able to communicate to others in English on the elementary level." In addition, the basic competence of teaching speaking is they can express various feelings or senses.

\section{The goal of Teaching Speaking}

The goal of teaching speaking is to develop the student's competence in communication by using English. The teacher said: "The goal of teaching 
speaking is to train the students to be able to communicate on the elementary level. In other words, students can share ideas and various feelings in English."

\section{Syllabus}

The syllabus for eleventh grade students of SMAN 1 Pelaihari is based on Kurikulum 2013. In Kurikulum 2013, the students should master English competence or the four language skills. They are listening, speaking, reading, and writing.

\section{The Material of Teaching}

\section{Speaking}

To be successful the speaking material above the English teacher needs a handbook. The teacher said: "The book used by the teacher is a module. It consists of certain materials and student's exercises."

\section{The Method of Teaching}

\section{Speaking}

The English teacher uses Communicative Language Teaching (CLT) as her method of teaching speaking. Below is the teacher's explanation about her method: "The method used by the teacher is the communicative approach." The goal of CLT is to enable students to learn and improve their speaking ability.

\section{The Technique of Teaching}

\section{Speaking}

The English teacher of SMAN I Pelaihari uses dialogue as a technique in teaching speaking. So, the students are asked to present their dialogues in front of the class.

\section{Classroom Management}

The students' activity is making conversation, discussion, and performing a dialogue in the class. The teacher said: "I usually give a task through conversation. The students asked to discuss the material then practice the conversation in front of the class. And the way to manage the class is by asking the students to sit in pairs and they are as one team."

\section{B. The Result of the Observation}

There were three meetings of the teaching learning process which was attended by the researcher. In the process of teaching, the teacher always used dialogue. 
The observation was conducted every Thursday, in $3^{\text {rd }}, 10^{\text {th }}$ and $17^{\text {th }}$ October 2019. The duration of each meeting was 2 x 45 minutes. The teaching and learning activity did in the classroom. The theme of the lesson was "Bargaining."

The teacher uses three-stages of activities namely pre activities, whilst activities and post activities. During teaching the class activity, the teacher does the opening, presentation, practice/activate, recycling and closing.

The researcher concluded that the teaching process through short dialogue run well.

\section{The Result of Document}

The result of this section is some proof that the researcher does research at class XI of SMAN 1 Pelaihari. In this section, the researcher gives proofs like the picture based on observation, teacher's RPP, and some sheets of paper an example of dialogue delivered by the teacher to students.

\section{CONCLUSION}

Based on the research result, the researcher concludes that:

1. During the process of teaching, the teacher uses three-stages of activities namely pre activities, whilst activities and post activities. In Pre activities, the teacher tried to focus on the students' attention. He greeted or asked the student's condition and checked the presence list. Before starting the lesson, the teacher tried to attract the students' attention by asking some questions related to the lesson yesterday. After asking some questions to the students, the teacher started the lesson for the day. In whilst activities the teacher introduced and explained the definition of the topic. After students understood the material, the teacher gave exercise by asking students to make a dialogue about bargaining, then he divided the students into pairs and asked them the topic was buying needs in the market and practice their dialogue in front of the class. And the post activities the teacher gave a conclusion about the material. He gave little information about the material that would be learning in the next meeting. Then, he closed the class by saying hamdallah together and thanked for the students' cooperation.

2. Teaching Speaking process through short dialogue is satisfying. By uses short dialogue the students can be mastering grammar, vocabulary and pronunciation which support English speaking skill. Besides that, the students have high confidence to speak English.

3. Teaching Speaking through short dialogue makes the class more interesting, more active and makes the students more motivated in learning and easier to grasp the lesson. 


\section{REFERENCES}

Bickerton, Derek. (1996). Communicative Language Teaching. Cambridge: Cambridge University Press.

Fraenkel, Jack R and Wallen, Norman E. (1993). How To Design an Evaluate Research In Education. New York: San Francisco State University.

Moleong, Lexy J. (1995). Metode Penelitian Kualitatif. Bandung: PT. Remaja Rosdakarya Mulyasa, Enco. 2002. Kurikulum Berbasis Kompetensi: Konsep, Karakteristik, dan Implementasi. Bandung: PT. Remaja Rosdakarya. 